\title{
Erratum: Less functional variants of TLR-1/- $6 /-10$ genes are associated with age
}

Lutz Hamann $^{1 *}$, Juozas Kupcinskas ${ }^{2,3}$, Luis C. Almanza Berrocal ${ }^{1}$, Jurgita Skieceviciene ${ }^{3}$, Andre Franke ${ }^{4}$, Ute Nöthlings ${ }^{5,6}$ and Ralf R. Schumann ${ }^{1}$

After publication of this study [1], the authors noticed that the spelling of author Luis C Berrocal Almanza's name was incorrect. The original version of this article has been updated to correct this. The publisher apologises for any inconvenience caused.

\begin{abstract}
Author details
'Institute of Microbiology and Hygiene, Charité University Medical Center Berlin, Charitéplatz 1, Berlin 10117, Germany. ${ }^{2}$ Department of

Gastroenterology, Lithuanian University of Health Sciences, Kaunas, Lithuania. ${ }^{3}$ Institute for Digestive Research, Lithuanian University of Health Sciences, Kaunas, Lithuania. ${ }^{4}$ University Hospital Schleswig Holstein, Campus Kiel, Schittenhelmstr. 12, Kiel, Germany. ${ }^{5}$ Popgen Biobank, Institute for

Experimental Medicine, Christian-Albrechts-University Kiel, Niemansweg 11, Kiel, Germany. ${ }^{6}$ Present address: Department of Nutrition and Food Sciences, Rheinische Friedrich-Wilhelms-University Bonn, Endenicher Allee 11-13, Bonn 53115, Germany.
\end{abstract}

Received: 4 August 2015 Accepted: 4 August 2015

Published online: 11 August 2015

\section{Reference}

1. Hamann L, Kupcinskas J, Berrocal Almanza LC, Skieceviciene J, Franke A,

Nöthlings $U$, et al. Less functional variants of TLR-1/-6/-10 genes are

associated with age. Immun Ageing. 2015;12:7.

\footnotetext{
* Correspondence: lutz.hamann@charite.de

'Institute of Microbiology and Hygiene, Charité University Medical Center
} Berlin, Charitéplatz 1, Berlin 10117, Germany

\section{Submit your next manuscript to BioMed Central and take full advantage of:}

- Convenient online submission

- Thorough peer review

- No space constraints or color figure charges

- Immediate publication on acceptance

- Inclusion in PubMed, CAS, Scopus and Google Scholar

- Research which is freely available for redistribution

Submit your manuscript at www.biomedcentral.com/submit
C Biomed Central 